\title{
Tiesību institūta - kriminālprocesa atjaunošana sakarā ar jaunatklātiem apstākḷiem - izcelsme un vēsturiskā attīstība
}

\author{
Mg. iur. Inese Baikovska \\ Biznesa augstskola "Turība", studiju programma "Juridiskā zinātne”, Latvija \\ baikovska@inbox.lv
}

\section{Kopsavilkums}

Šajā rakstā pievērsta uzmanība tiesību institūta - kriminālprocesa atjaunošana sakarā ar jaunatklātiem apstākḷiem - izpētei, atspoguḷojot tā izcelsmi, ieviešanu tiesiskajā regulējumā un vēsturisko attīstību.

Pētỉjumā apkopota un analizēta tiesību institūta ieviešanas kriminālprocesuālajā regulējumā vēsturiskā gaita, tostarp ieviešana Latvijas kriminālprocesuālajā regulējumā, kurā ši institūta pirmsākumi meklējami jau no tiesu nospriestā, t. i., spriedumu pārsūdzības institūtu rašanās.

Rakstā akcentēta tiesību institūta nozīmīgā loma Latvijas kriminālprocesuālo likumu regulējumos, kuri vēstures gaitā mainās, taču tajos tiek saglabāti galvenie tiesību principi - nodrošinātas tiesības uz taisnīgu tiesu, kā arī cilvēktiesību garantijas.

Atslēgvārdi: kriminālprocess, jaunatklāti apstākḷi, kriminālprocesa atjaunošana.

\section{levads}

Pētot tiesību institūta - kriminālprocesa atjaunošana sakarā ar jaunatklātiem apstākḷiem - vēsturisko izcelsmi, sākotnējie meklējumi jāsaista ar kriminālprocesa kā atsevišķa tiesību institūta veidošanos. Aplūkojot šo jautājumu vēsturiski, redzams, ka kriminālprocesuāās tiesības nebija atsevišḳi nodalītas un saplūda kopā ar civilprocesuālo kārtỉbu, proti, visu kategoriju lietas tika iztiesātas ar vienu procesuālo kārtību. Lai vēsturiskā kontekstā aplūkotu tiesību institūta - kriminālprocesa atjaunošana jaunatklātu apstākḷu dēl - izcelšanos un ieviešanu tiesību normās, sākotnējie meklējumi vēršami vispirms uz tiesu nospriesto, t. i., spriedumu pārsūdzēšanas kārtību un nolēmumu pārsūdzības institūtu rašanos. 
Raksta mērḳis ir atainot tiesību institūta - kriminālprocesa atjaunošana sakarā ar jaunatklātiem apstākḷiem - izcelšanos, institūta nostiprināšanu Latvijas un ārvalstu tiesību normās, kā arī tā vēsturiskās attīstības tendences. Publikācijā atspoguḷoti rezultāti, kas gūti pētījumā par vēsturiskajiem kriminālprocesuālajiem regulējumiem Latvijā un ārvalstīs, kā arī šie rezultāti salīdzināti. Tiek arī izteikti secinājumi par tiesību institūta izcelšanos, vēsturisko attīstību un nozīmīgo lomu kriminālprocesuālajā regulējumā.

Pētijjums balstīts uz normatīvo aktu, atziṇu un viedokḷu analīzi. Tã izstrādē tika izmantota vēsturiskā metode, pētot konkrētā tiesību institūta izcelsmi un vēsturisko attīstību; analīzes un sintēzes metode, analizējot dažādu valstu tiesiskā regulējuma kopsakarības un atškịīibas; salīdzināmā metode, salīdzinot konkrētas tiesību normas ar citām normām līdzīgos tiesiskajos regulējumos.

\section{Tiesas spriedumu pārsūdzības institūtu attīstības pirmsākumi}

Par kriminālprocesa teorētisko priekšstatu sākumu var uzskatīt 2.-3. gadsimtu, t. i., romiešu jurisprudences "zelta gadsimtu", kad darbojās vairākas izcilas personības, piemēram, Papiniāns, Pāvels un Ulpiāns [26]. Šie pētnieki pirmie radīja teorētiskos priekšstatus par tiesāšanu, pierādījumiem un prezumpciju. Ulpiāns bija pirmais, kas formulēja nostādni, kura līdzinās mūsdienu nevainīguma prezumpcijas principam [29, 34].

Aplūkojot senās Romas tiesības, redzams, ka, piemēram, Divpadsmit tabulu likumos (Leges duodecim tabularum) bija paredzēts tāds tiesību institūts kā provocatio ad populum, kura būtība bija šāda: par valsts varas nesēju kriminālspriedumu notiesātajam bija tiesības vērsties ar sūdzību pie tautas sapulces [12, 78]. Šìs ir liecỉbas par pirmajiem mēǵinājumiem ieviest tiesas nospriestā pārsūdzības institūtu.

Romiešu tiesībās sākotnēji tiesvedības procesi civilās lietās un lietās par noziegumiem, t. i., kriminālās tiesvedības, netika nodalīti. Tomēr, pārdzīvojot vairākas attīstības stadijas, Romas republikas laikā izveidojās kriminālprocess. Tautas tribūniem bija tiesības uzraudzīt tiesnešu rīcību tiesas procesā, turklāt viṇi varēja rosināt spriedumu pārsūdzēt tautas sapulcē - provocatio ad populum [9, 79-80]. Šeit minētais lauj secināt, ka kriminālprocesa tiesībās sprieduma pārsūdzības institūts parādījās jau Romas republikas laikā.

1532. gadā Vācijā tika izdots krimināltiesību un kriminālprocesa kodekss, kuru dēvēja par Karolīnu (Constitutio Criminalis Carolina jeb Peinlishe Gerichtsordnung), kas bija spēkā līdz pat 1870. gadam, un raksturīgi, ka tajā bija paredzēti seviški bargi sodi, it īpaši - miesas sodi, spīdzināšana. Šim kriminālprocesam bija inkvizīcijas raksturs, un pārsūdzēt tiesas nolemto nebija iespējams [10, 25].

Latvijas senajiem iedzìvotājiem, tāpat kā visām senajām tautām, sākotnējās krimināltiesību normas bija cieši saistītas ar asinsatriebības un izpirkuma maksas paražām [15, 28]. Viṇiem tiesu sprieda sapulcēs, kurām bija gan visas tautas sanāksmju, gan militāru sanāksmju, gan arī vecāko sapulču pazìmes, t. i., taisnība parasti tika uzzināta ar zīlēšanu 
vai tā saukto dieva tiesu $[15,29-30]$. No vēstures liecībām secināms, ka senajos laikos tiesas spriešana notika ātri, bez izmeklēšanas, pierādījumu vākšanas un pārbaudes, kā arī bez jebkādas iespējas nospriesto pārsūdzēt.

Vēstures dati liecina, ka pārsūdzību procesi Latvijas teritorijā parādījušies Livonijas laikā. Vācijas augstākā tiesa (Reichskammergericht) tika dibināta 1495. gadā, tajā tiesāja atbilstīgi romiešu tiesībām, un šìs tiesas jurisdikcijā bija arī Livonija. Vãcu muižniekiem bija tiesības tiesāties šajā Vācijas augstākajā tiesā, savukārt Livonijas vietējiem iedzīvotājiem tas bija liegts. Livonijas tiesas spriedumus varēja pārsūdzēt Vācijas augstākajā tiesā. [15, 72]

Livonijas laika zemnieku tiesību avoti liecina par pārsūdzības neiespējamību prāvās. Zemnieku lietās spriedumi bija galīgi un nepārsūdzami, un tos izpildīja nekavējoties $[15,101]$. Pētỉjumi liecina, ka Vācijā pien̦emto Karolīnu piemēroja arī Latvijas (toreiz Livonijas) tiesās, piemēram, 1535. gadā Valmieras tiesā tika lietots Karolīnas inkvizīcijas process $[11,28]$. No minētā var secināt, ka tiesas spriešanas procesos tika piemēroti atšşirīgi tiesiskie regulējumi, n̦emot vērā personas stāvokli sabiedrībā, tādējādi spriedumu pārsūdzēěanas tiesības bija tikai muižnieku kārtas iedzīvotāju privilēgija, savukārt zemākas kārtas iedzīvotājiem šādas tiesības bija liegtas.

Pētot jautājumu par pārsūdzības institūta ieviešanu tiesību normās, noteikti jāpiemin Livonijas laika, 1561. gada, Sigismunda Augusta privilègija (Privilegium Sigismundi Augusti), kurā tika noteikta lietu izskatīšana apelācijas kārtībā [7, 80]. Jau 16.-17. gadsimtā Rīgā tiesu procesos civilprocesu nodalīja no kriminālprocesa. Rīgas rāte 1581. gadā pieñēma Tiesāšanās noteikumus, kas bija vācu valodā un kuros tika paredzēta zemākas tiesas spriedumu pārsūdzēšana apelācijas kārtībā Rīgas rātē, kas tajā laikā bija augstākā apelācijas tiesa Rīgā [20, 289-290]. Tomēr šajos abos pieminētajos dokumentos nav norādes, ka apelācijas tiesas spriedumu varētu pārsūdzēt kādā augstākā tiesas institūcijā vai arī vēlāk atjaunot lietu, ja atklātos kādi jauni apstākḷi vai pierādījumi.

Valdības formulā (Formula Regiminis, tās pilnais nosaukums - Formula Regiminis in Ducata Curlandiae et Semigalliae), kas tika pien̦emta 1617. gadā un bija spēkā tagadējās Latvijas teritorijā, bija noteikts, ka muižnieku krimināllietās pastāv apelācijas iesniegšanas tiesības, bet pastāvēja arī izṇēmumi - publiski noziegumi, laupīšana, dedzināšana, izvarošana, sieviešu nolaupīšana, ar krāpšanu vai viltu izdarītas slepkavības vai laupišanas lietas, kurās apelācija netika piel̦auta. Nekāda cita tiesvedības atjaunošana vai sprieduma pārskatī̌sana netika piel̦auta [7, 213].

18. gadsimtā notika strauja tiesību zinātnes attīstība, kā arī cilvēka tiesības aizstāvošo normu ieviešana tiesiskajos regulējumos. Tiesību zinātnieks Monteskjē ir atzinis, ka brīvības nodrošināšanai nepieciešamas noteiktas tiesvedības procedūras un procesuālie noteikumi tādā pakāpē, lai tie sekmētu likuma realizācijas mērḳus, bet nepārvērstos par šķēršliem šo mērḳu realizācijai [25, 477].

Savukārt vispārējie kriminālprocesa principi Baltijā iezīmējās tikai 18. un 19. gadsimtā Krievijas impērijas laikā. Krievijas valdība izdeva impērijas Kriminālprocesa ustavu jeb nolikumu (Устав уголовного судопроизводства), kas 1889. gadā stājās spēkā arī Baltijas gubern,ās, un tas bija prasmīgi pieskan,ots Baltijas ìpatnībām [15, 350-351]. 
Latvijas teritorijā kopš 1889. gada bija spēkā šis Krievijas impērijas 1864. gada Kriminālprocesa ustavs. Tika paredzēts, ka apgabaltiesas spriedumu krimināllietās var pārsūdzēt apelācijas kārtībā tiesu palātā, bet kasācijas kārtībā - Senātā. Turklāt ārkārtas gadījumos, ja kḷuva zināmi no jauna atklājušies apstākḷi un tika konstatēts, ka tiesa kḷūīijusies, prokuratūra, cietušais vai viṇa radinieki varēja ierosināt tiesas pieṇemtā sprieduma revīziju [13, 32-33].

Savukārt ar 1919. gada 5. decembra Tautas padomes pieñemto likumu "Par agrāko Krievijas likumu spēkā atstāšanu Latvijā” Latvija kḷuva par Krievijas tiesību mantinieci $[18,144]$. Tomēr tika paturētas tiesības atcelt, grozīt vai papildināt šìs Krievijas tiesības, tādējādi nodrošinot tiesību kontinuitāti jeb pēctecību [19, 177].

Pēc Latvijas valsts nodibināšanas un Latvijas Republikas parlamentārajā posmā (1922-1934) kriminālprocesa tiesību galvenais avots bija jau iepriekš minētais, 1889. gadā uz Baltijas valstīm attiecinātais, 1864. gada Krievijas Kriminālprocesa ustavs, kurš tika grozìts un papildināts atbilstīgi Latvijas apstākḷiem [13, 256]. Jau tā laika tiesību zinātnieki atzina, ka kriminālprocesuālajā regulējumā jāparedz gadijumi, ka var atjaunot lietu pēc tiesas sprieduma spēkā stāšanās, ja atklājas jauni fakti, kas nebija zināmi tiesai un kas dod lielu pārliecību, ka notiesātais nav vainīgs un pieṇemtais tiesas spriedums būtu citāds, ja šie fakti būtu zināmi. Šāda sprieduma atstāšana spēkā vienmēr būs neizbēgami saistīta ar lieliem zaudējumiem gan taisnīgas tiesas nodibināšanai, gan iesaistītajām personām, un, lai no šādiem gadījumiem izvairītos, valsts ir iedibinājusi lietu, kurās spriedums stājies spēkā, atjaunošanas institūtu [27, 542].

Arī autoritārā režìma laikā (1934-1940) Latvijā kriminālprocesuālo tiesību jomā kā pamatavots palika 1864. gada Krievijā kodificētais Kriminālprocesuālo tiesību ustavs jeb nolikums, kuru Latvijas Republikā pārtulkoja latviešu valodā un nosauca par Kriminālprocesa likumu, kas bija spēkā visu autoritārā režìma laiku [13, 278].

Var secināt, ka ar šo Krievijas impērijas Kriminālprocesa nolikumu kriminālprocesuālajās tiesībās parādījās pirmās liecības par tādiem tiesību institūtiem kā "jaunatklāti apstākḷi" un "lietas atjaunošana jaunatklātu apstākḷ dệ". Tas uzskatāms par pozitīvu virzienu kriminālprocesa attīstībā un cilvēka tiesību nodrošināšanā, tālāk veicinot tiesību principa - tiesības uz taisnīgu tiesu - kā pamatprincipa attīstību un piemērošanu tiesu praksē.

\section{Tiesību institūts - kriminālprocesa atjaunošana jaunatklātu apstāḳ̣u dēḷ - tiesību normās Latvijā un ārvalstīs, tā vēsturiskā attīstība}

Francijā pirmais Kriminālprocesa kodekss tika pieṇemts 1808. gadā. To apstiprināja Napoleons, un tas tika piemērots 150 gadus, līdz pat 1959. gadam [14, 9]. Tika atzìts, ka tiesvedības kḷūdas bieži vien noved pie lietas pārskatišanas no jauna, pamatojoties uz jauniem pierādījumiem. Procesa atvēršana no jauna tika dēvēta par revīziju (revision), un tā tika ieviesta ap 1890. gadu. Tā paredzēja kriminālprocesa atjaunošanas procedūru, ja parādijjās jauni, iepriekš nezināmi fakti, kas vieš šaubas par notiesāšanu $[8,139]$. 
Francijā tika atzìts, ka sprieduma patiesības princips ir tik stiprs, ka pat sprieduma izpildīšanas laikā ar atsevišḳiem nosacījumiem ir atḷauta pārbaudī̌ana - tā ir atjaunošana, kas iespējama tikai sevišḳi svarīgos gadījumos. Tā pamatojas uz to, ka spriedumā ir tiesas kḷūda (piemēram, ja persona notiesāta par slepkavību, bet vēlāk izrādās, ka upuris ir dzīvs), vai arī uz to, ka spriedums radies noziedzīgā kārtā (vēlāk uzzina, ka liecinieki melojuši vai tika viltots dokuments). Francijā tika izstrādāts īpašs jēdziens - "vēlāko jauno faktu" jēdziens. Tika atzìts, ka šie fakti ir tik svarīgi, ka tiesa, ja tā zinātu šos faktus, būtu taisījusi citādu spriedumu un, ja šādi fakti atklājas, prāva tiek atjaunota un notiek vēlreizēja iztiesāšana [17, 130-131].

Krievijas kriminālprocesa vēsturiskajā attīstībā jautājums par lietu izskatīšanu vēlreiz jaunatklātu apstākḷu dẹl likumīgu regulējumu ieguva ar 1864. gada Kriminālprocesa ustavu. Iepriekš šāds institūts (par lietu atjaunošanu jaunatklātu apstākḷu dẹḷ) nevienā kriminālprocesu regulējošã dokumentā nav atspoguḷots [16, 5-6].

Jāpiebilst, ka Krievijas kriminālprocess tika veidots pēc Francijas kriminālprocesa modela $[28,6]$. Var secināt, ka Krievijas kriminālprocesuālajā regulējumā tika ieviestas cilvēka tiesības garantējošās normas, ietekmējoties no Francijas kriminālprocesa, tomēr tiesību institūts - lietas atjaunošana jaunatklātu apstākḷu dēl - Krievijas kriminālprocesuālajā regulējumā tika ieviests pirmo reizi, jo iepriekš šāda tiesību institūta citās valstīs nebija.

Latvijā pirmais likums latviešu valodā, kurā parādās regulējums par krimināllietu atjaunošanu jaunatklātu apstākḷu dẹl, tika pieñemts 1926. gadā Kriminālprocesa likumos [3]. Šì tiesiskā akta vispārīgo noteikumu dal̦as 29.-31. pantā noteikts, ka lietu var atjaunot, ja atklājas pierādījumi par notiesātā nevainību vai arī tiesas kḷùda, ar kuru piespriests lielāks sods, nekā notiesātais noziedzies. Tajā arī noteikts, ka nevainīgi notiesātajam atdot viṇa godu un tiesības aț̣auts katrā laikā, neraugoties ne uz noilguma termiṇa beigām, ne uz notiesātā nāvi. Savukārt, ja lieta par apsūdzēto bijusi izbeigta, tad to atjaunot var vienīgi noilguma termiṇa laikā. No Kriminālprocesa likumu ievaddaḷā definētā var secināt, ka šāds regulējums lielākoties pārṇemts no Krievijas Kriminālprocesa likuma vispārējiem noteikumiem un šì regulējuma pien̦emšana datēta ar 1864. gada 20. novembri. Tāpat minētajā tiesību aktā bija paredzēta galīgo spriedumu atcelšanas kārtība, t. i., 212. pantā tika noteikts, ka lietu var atjaunot, ja atklāti jauni apstākḷi vai pierādījumu viltojums, uz kuriem dibināts likumīgā spēkā nākušais miertiesneša vai apgabaltiesas spriedums. Arī no tā var secināt, ka minētais regulējums, kā tas norādīts Kriminālprocesa likumos, ir pieñemts jau 1885. gada 19. novembrī. Šajos Kriminālprocesa likumos (955. pantā) parādās jau konkrēts definējums, norādot apstākḷus, kas tika atzìti par likumīgiem lietu atjaunošanai:

- ja vairākas personas ar dažādiem spriedumiem bija notiesātas par vienu un to pašu noziedzīgu nodarījumu, kura izdarǐšana no viena notiesātā puses pierāda, ka to nav bijis iespējams izdarīt kādam citam notiesātajam;

- ja kāda persona notiesāta par cilvēka slepkavību, kurš vēlāk izrādīiies dzīvs, vai par citu noziedzīgu nodarijumu, kas nav noticis, un par tādu pierādījumu atklāšanu, kuri norāda, ka notiesātais nav vainīgs, vai arī tiesas kḷūdas dēl ir cietis lielāku sodu, nekā viṇa nodarījums paredzējis; 
- ja atklājas dokumenta viltojums vai nepatiesas liecības, uz kuriem dibināts spriedums;

- ja tiesas ceḷā ir pierādīti tiesnešu mantkārīgi vai citi personīgi nolūki tajā lietā, par kuras atjaunošanu ir lūgumi vai iesniegumi.

Kā redzams, minētais definējums deva tiešas norādes, kuros gadījumos varēja atjaunot izmeklēšanu krimināllietās, tomēr secināms, ka tas ir visai atšḳirīgs no pašlaik spēkā esošā kriminālprocesuālā regulējuma.

Skaidrojot krimināllietu atjaunošanas regulējumu, tā laika tiesību pētnieku izteikumos parādās arī taisnīgas tiesas jēdziens. Tika atzîts, ka Latvijā attaisnojošu spriedumu var atcelt, lai arī tas nāktu par ḷaunu notiesātajam, un tas saskan ar taisnas tiesas un pareizības atklāšanas būtību [32, 183]. Tiesību zinātnieki bija nonākuši pie konsekvences, ka pēc būtības nepareizs spriedums, kaut arī tas būtu stājies likumīgā spēkā, nav saistošs un nav arī izpildāms. Līdz ar to katrā šādā reizē nākas sastādīt atsevišḳu tiesisku aktu, kas konstatētu, ka valsts sodīšanas tiesība atkritusi [21, 24].

Kopumā par minēto Kriminālprocesa likumu normu skaidrojumu atrodami viedokḷi, ka Latvijā prāvas atjaunošanas process koncentrējas Senāta krimināldepartamentā (pēc franču parauga), kurā iniciatīva ir prokuroram, notiesātajam vai arī viṇa radiniekiem. Lūgums jāiesniedz tieši Senātam, kurš pārbauda, vai tiešām radies jauns svarīgs fakts, un šāda fakta esamības gadījumā atcel spriedumu un nodod lietu zemākai tiesai. Šie noteikumi bija vispārīgām tiesām, bet miertiesnešiem no 1912. gada bija citi noteikumi, kuros paredzēts, ka lūgumus iesniedz tieši miertiesai vai apgabaltiesai, ja tā pēdējā skatījusi lietu. Ja lūgumu par jaunatklātiem apstākḷiem tiesa noraida, tad sūdzību var iesniegt Senātam, kura nolēmums ir galīgs [17, 131-132].

Apkopojot iepriekš aprakstīto, var secināt, ka kriminālprocesuālajās tiesībās Latvijā tiesību institūts, kas regulē krimināllietu atjaunošanu jaunatklātu apstākḷ dẹl, tika ieviests, pamatojoties uz Krievijas tā laika regulējošām normām. Lai arī vēsturiskajos rakstos rodamas atsauces uz franču kriminālprocesuālo regulējumu, manuprāt, tomēr pamatā Latvijas teritorijā esošais regulējums ticis pārṇemts no Krievijas regulējuma, kurā savukārt nenoliedzami bijusi Francijas ietekme, it īpaši cilvēka pamattiesību garantiju jautājumos.

Vēlāk, atrodoties Padomju Sociālistisko Republiku Savienības (PSRS) sastāvā (1940-1941), 1940. gadā no 21. jūlija līdz 26. novembrim Latvijā tika piemērots Kriminālprocesa likums, kas tika dēvēts par gãztās valdības likumu [23, 52]. Savukārt ar 1940. gada 26. novembri Latvijas Padomju Sociālistiskajā Republikā (LPSR) stājās spēkā Krievijas Padomju Federatīvās Sociālistiskās Republikas (KPFSR) 1923. gada Kriminālprocesa kodekss. Padomju kriminālprocesuālās tiesības paredzēja tiesas spriedumu pārskatīšanas divus veidus - kasācijas un uzraudzības kārtībā [13, 344]. Tomēr, ņemot vērā tā laika politisko situāciju, šis kriminālprocesuālais regulējums Latvijā pastāvēja vien īsu brīdi.

Nacistiskās Vācijas okupācijas periodā (1941-1945) Latvijā saistoši bija 1943. gada 8. novembrī izdotie noteikumi "Par vietējo kriminālprocesa likuma priekšrakstu saskaṇojumu ar vācu kriminālprocesa likumu Latvijas generālapgabalā", kas stājās spēkā 1943. gada 1. decembrī. Šajos noteikumos tika piel̦auta krimināllietas atjaunošana, ja 
Inese Baikovska. Tiesību institūta - kriminālprocesa atjaunošana sakarā

ar jaunatklātiem apstākḷiem - izcelsme un vēsturiskā attīstība

tika iesniegti jauni pierādījumi, kas paši par sevi vai kopā ar agrākajiem varēja noderēt par pamatu:

- notiesātā attaisnošanai vai arī ievērojami vieglāka soda piespriešanai, vai lietas izbeigšanai notiesāšanas vietā;

- attaisnotā notiesāšanai vai ievērojami smagāka soda piespriešanai;

- ievērojami citāda lēmuma taisišanai sabiedrības aizsardzības un labošanas līdzekḷu piemērošanai $[13,362]$.

Var secināt, ka minētais regulējums lāàa atjaunot tiesvedību krimināllietās, ja tika iegūti kādi jauni pierādỉjumi vai fakti, lai notiesātajam uzlabotu tiesisko stāvokli vai arī to pasliktinātu.

Vēlāk sekojošajā padomju tiesību periodā (1944/45-1985) Latvijā (1944. gadā daḷā Latvijas, bet 1945. gada maijā visā teritorijā tika atjaunots PSRS režīms) pēc Otrā pasaules kara tiesību jomā tika atjaunota situācija, kas bija izveidojusies 1940./1941. gadā [13, 373]. Tātad Latvijā atkal bija spēkā KPFSR 1923. gada Kriminālprocesa kodekss, kurā paredzēts atjaunot krimināllietu arī jaunatklātu apstākḷu dēḷ.

Lietu atjaunošanas kārtība un to jauna caurskatīšana varēja notikt tādēl, ka bija atklājušies jauni apstākḷi, kas nebija atradušies pirmās instances tiesas redzeslaukā, taisot spriedumu, vai bija atklājušās spriedumu taisījušo tiesnešu noziedzịgas launprātības [31, 497]. Savukārt lietu atjaunošana jaunatklātu apstākḷu dēl nebija ierobežota ar termiņiem, iznēemums bija tikai attaisnojoša sprieduma jauna caurskatišana, kas varēja notikt viena gada laikā no jaunu apstākḷu atklāšanās dienas un ne vēlāk par pieciem gadiem no tās dienas, kad attaisnojošais spriedums stājies likumīgā spēkā [30, 313].

Var secināt, ka, bieži mainoties politiskajai situācijai, Latvijā tika mainīti situācijai atbilstīgi kriminālprocesuālie likumi, tomēr šajos kriminālprocesuālajos regulējumos tika saglabāts tiesību institūts, kas paredzēja atjaunot lietu, pamatojoties uz jaunatklātiem apstākḷiem. Tādējādi šis tiesību institūts stabili nostiprinājās kriminālprocesuālajās tiesībās kā neatṇemama kriminālprocesuālo likumu sastāvdaḷa, stiprinot tiesību uz taisnīgu tiesu principa garantijas.

Vēlāk, 1961. gada 6. janvārī, tika pieṇemts LPSR Kriminālprocesa kodekss [4], kas stājās spēkā 1961. gada 1. aprīlī. Šajā Kriminālprocesa kodeksā noteiktais regulējums paredzēja spriedumu pārsūdzību tikai kasācijas un uzraudzības kārtībā. Kriminālprocesa kodeksā bija paredzēts uzraudzības tiesvedības institūts - uzraudzības tiesvedība ir kriminālprocesuāla stadija, kurā pēc likuma pilnvarotu personu protestiem tiek izskatìta likumīgā spēkā stājušos tiesas spriedumu likumība un pamatotība, bet protestus varēja iesniegt tikai likuma pilnvarotas tiesu un prokuratūras amatpersonas [22, 244-245]. Kriminālprocesuālais regulējums paredzēja arī krimināllietas atjaunošanu sakarā ar jaunatklātiem apstākḷiem, kas bija patstāvīga tiesvedības stadija, un ši ārkārtējā tiesvedība varēja notikt tikai gadījumā, ja lietā, kurā spriedums stājies likumīgā spēkā, atklājas jauni apstākḷi, kuri pirms tam nav bijuši konstatēti un nav bijuši zināmi ne izmeklēšanas orgāniem, ne tiesai, bet kuru pastāvēšana var likt apšaubìt tiesas sprieduma vai lēmuma likumību un pamatotību [22, 260].

1961. gadā pieṇemtais LPSR Kriminālprocesa kodekss ar daudzkārtējiem grozījumiem un papildinājumiem tika piemērots arī pēc Latvijas Republikas neatkarības 
atjaunošanas. Ar 1991. gada 21. augusta likumu [5] tika noteikts, ka LPSR Kriminālprocesa kodekss uzskatāms par Latvijas Kriminālprocesa kodeksu. Pēc tam šajā kodeksā vairākkārtīgi tika grozītas normas, kas regulēja lietas atjaunošanu jaunatklātu apstākḷu dēḷ. Tiesību pētnieki atzinuši, ka no 1990. līdz 2005. gadam notika būtiskas izmaiṇas Latvijas Kriminālprocesa kodeksā. Galvenokārt tās noteica pāreja uz citu tiesību saimi un starptautisko cilvēktiesību garantiju ieviešana, kā arī straujās sabiedriskās pārmaiṇas [24, 34].

2005. gada 1. oktobrī stājās spēkā Kriminālprocesa likums [2], kurā regulējums par kriminālprocesa atjaunošanu sakarā ar jaunatklātiem apstākḷiem (62. nodaḷa) galvenokārt tika pārn,emts no iepriekšējā regulējuma - Latvijas Kriminālprocesa kodeksa. Tomēr pēc Kriminālprocesa likuma stāšanās spēkā arī šis regulējums vairākkārtīgi tika grozīts (piecas reizes) un pilnveidots. N̦emot vērā kriminālprocesuālo tiesību normu attīstību, radās nepieciešamība arī grozīt normas, kas regulē tiesību institūtu - kriminālprocesa atjaunošana jaunatklātu apstākḷu dēḷ. Būtiskākie un plašākie grozỉjumi minētajā regulējumā tika pieṇemti 2017. gada 30. martā [1]. To pieṇemšanas pamatā bija Satversmes tiesas 2016. gada 29. aprīl spriedums lietā Nr. 2015-19-01 [6]. Satversmes tiesa nosprieda atzìt Kriminālprocesa likuma 657. panta pirmo, trešo un piekto daḷu, ciktāl tās piel̦auj to, ka prokurors, kurš kriminālprocesā veicis izmeklēšanas darbības, izmeklēšanas uzraudzību, kriminālvajāšanu vai uzturējis valsts apsūdzību, izlemj jautājumu par šì kriminālprocesa atjaunošanu sakarā ar jaunatklātiem apstākḷiem, par neatbilstošām Latvijas Republikas Satversmes 92. panta pirmajam teikumam. Pieņemot šos grozījumus, Kriminālprocesa likuma normas tika grozītas, lai nodrošinātu kriminālprocesā iesaistìto personu tiesības uz taisnīgu tiesu un tiesības vērsties ar pieteikumu par procesa uzsākšanu jaunatklātu apstākḷu izmeklēšanai un šādu pieteikumu izskatìtu neatkarīgs prokurors, kurš iepriekš nav bijis kādā veidā saistīts ar konkrēto kriminālprocesu, t. i., nav veicis izmeklēšanas darbības, uzraudzību, kriminālvajāšanu vai piedalīiies lietas izskatīšanā tiesā.

Var secināt, ka tiesību institūtam - kriminālprocesa atjaunošana jaunatklātu apstākḷu dēl - ir nozīmīga loma tiesību uz taisnīgu tiesu nodrošināšanā. Tomēr vēsturiskā kontekstā redzams, ka šì tiesību institūta regulējums tiek pilnveidots atbilstīgi nepieciešamībai pilnvērtīgi nodrošināt cilvēka pamattiesības. Šì tiesību institūta normatīvais regulējums arī turpmāk varētu tikt grozìts, papildināts un pilnveidots, jo tiesību attīstība virzās līdzi sabiedrības un to vērtību attīstības tendencēm.

\section{Secinājumi}

1. Ar 1864. gada Krievijas impērijas Kriminālprocesa ustavu jeb nolikumu ( $Y_{c m a B}$ уголовного судопроизводства) kriminālprocesuālajās tiesībās parādījās pirmās liecības par tādiem tiesību institūtiem kā "jaunatklāti apstākḷi" un "lietas atjaunošana jaunatklātu apstākḷu dẹḷ”. Tas uzskatāms par pozitīvu virzienu kriminālprocesa attīstībā un cilvēka tiesību nodrošināšanā, kas veicināja tiesību principa - tiesības uz taisnīgu tiesu - kā pamatprincipa attīstību un piemērošanu tiesu praksē. 
2. Latvijā pirmais likums latviešu valodā, kurā ietverts regulējums par krimināllietu atjaunošanu jaunatklātu apstākḷ dẹl, bija 1926. gada Kriminālprocesa likumi, kuru regulējums galvenokārt tika pārṇemts no Krievijas 1864. gada Kriminālprocesa nolikuma. Kriminālprocesa likumos tika dots tiešs definējums, kuros gadījumos var atjaunot izmeklēšanu krimināllietās, tomēr šie nosacījumi diezgan būtiski atškiras no pašlaik pastāvošā kriminālprocesuālā regulëjuma.

3. Latvijā kriminālprocesuālajās tiesībās tiesību institūts - krimināllietu atjaunošana jaunatklātu apstākḷu dēl - tika ieviests, pamatojoties uz Krievijas tā laika regulējošām normām. Lai arī vēsturiskajos rakstos rodamas atsauces uz franču kriminālprocesuālo regulējumu, tomēr Latvijas teritorijā esošais regulējums pārṇemts no Krievijas kriminālprocesuālā regulējuma, kurā savukārt nenoliedzami redzama Francijas ietekme.

4. Vēsturiski mainoties politiskajai situācijai, Latvijā tika mainīti un situācijai piemēroti kriminālprocesuālie likumi, tomēr šajos kriminālprocesuālajos regulējumos jau no 1889. gada Latvijas teritorijā tika saglabāts tiesību institūts, kas paredzēja atjaunot lietu, pamatojoties uz jaunatklātiem apstākḷiem.

5. Kriminālprocesa likumā tiesību institūts - kriminālprocesa atjaunošana sakarā ar jaunatklātiem apstākḷiem (62. nodaḷa) - tika pārṇemts no Latvijas Kriminālprocesa kodeksa. Šis regulējums pēc Kriminālprocesa likuma stāšanās spēkā tika grozìts piecas reizes, un tiesiskais regulējums tika pilnveidots, ņemot vērā nepieciešamību pēc tāda kriminālprocesuālā regulējuma, kas garantētu personu tiesības uz taisnīgas tiesas nodrošināšanu.

6. Tiesību institūtam - kriminālprocesa atjaunošana jaunatklātu apstākḷ dēl - ir nozīmīga loma tiesību uz taisnīgu tiesu nodrošināšanā, un tā regulējums laika gaitā tiek pilnveidots atbilstīgi nepieciešamībai pilnvērtīgi nodrošināt cilvēka pamattiesības. Šì tiesību institūta normatīvais regulējums arī turpmāk varētu tikt grozīts, papildināts un pilnveidots, jo tiesību attīstība virzās līdzi sabiedrības un to vērtību attīstības tendencēm.

\section{Origination and Historical Development of Legal Institution - Renewal of Criminal Proceedings Due to Newly Disclosed Circumstances}

\section{Abstract}

The article examines a legal institution concerning the re-opening of criminal proceedings due to newly disclosed circumstances, focusing on the origin of this institution, its introduction into legislation and historical development. 
Inese Baikovska. Tiesību institūta - kriminālprocesa atjaunošana sakarā

ar jaunatklātiem apstākḷiem - izcelsme un vēsturiskā attīstība

The research aggregates and analyses historical progress of how the legal institution has been introduced into legislation governing criminal procedure, including the legislation of the Republic of Latvia, where this institution goes back to the emergence of the institution of appeals against court rulings.

The article leads to the conclusion that the legal institution has a significant role in the Latvian legislation governing criminal procedure, which, as a result of historical changes, respects the fundamental principles of law, i.e. the guaranteed right to a fair trial and human rights.

Keywords: criminal procedure, newly disclosed circumstances, reopening criminal procedure.

\section{Avoti un literatūra}

\section{Tiesību akti}

1. Grozījumi Kriminālprocesa likumā: Latvijas Republikas likums. Latvijas Vēstnesis. 132(5959), 05.07.2017.

2. Kriminālprocesa likums: Latvijas Republikas likums. Latvijas Vēstnesis. 74(3232), 11.05.2005.

3. Kriminālprocesa likumi: Saeimas kodifikācijas nodaḷas 1926. gada izdevums. Latvijas Universitāte. Iegüts no: https://dspace.lu.lv/dspace/handle/7/1284?show=full [sk. 27.12.2017.].

4. Latvijas Padomju Sociālistiskās Republikas Kriminālprocesa kodekss. Rīga: Latvijas Valsts izdevniecība, 1961.

5. Par grozijumiem un papildinājumiem Latvijas PSR kriminālkodeksā un Latvijas PSR kriminālprocesa kodeksā. Ziñotājs. 33/34, 29.08.1991.

\section{Tiesu prakse}

6. Satversmes tiesas 2016. gada 29. aprīla spriedums lietā Nr. 2015-19-01. Latvijas Vēstnesis. 85(5657), 03.05.2016.

\section{Literatūra}

7. Apsìtis, R., Blūzma, V., Lazdinšs, J. Latvijas tiesību avoti. Teksti un komentāri. 2. sēj. Rīga: Juridiskā koledža, 2006.

8. Bell, J., Boyron, S., Whittaker, S. Principles of French law. New York: Oxford University Press, 1998.

9. Birziña, L. Romiešu tiesību vēsture. Rīga: Poligrāfists, 1996.

10. Birziṇa, L. Vācijas valsts un tiesības feodālisma periodā (X-XVIII gs.). No: Vispārējā valsts un tiesību vēsture. Rīga: P. Stučkas Latvijas Valsts universitāte, 1976.

11. Birziṇa, L. Viduslaiku Vācijas tiesību vēsture: Mãcību līdzeklis. Rīga: LR Nacionālā aizsardzības akadēmija, 1995.

12. Blūzma, V., Osipova, S., Zemītis, G. Ārvalstu tiesību vēstures avoti. Rīga: Biznesa augstskola "Turība", 2007.

13. Dītrihs, A. L. Latvijas tiesību vēsture (1914-2000). Rīga: Latvijas vēsture, 2000.

14. Gutcenko, K. F., Golovko, L. V., Filimonov, Iu. A. Ugolovnyi process zapadnykh gosudarstv. Moskva: Zertcalo-M, 2001. (Гуценко, К. Ф., Головко, $\Lambda$. В., Филимонов, Ю. А. Уголовный процесс западных государств. Москва: Зерцало-М, 2001).

15. Kalniňš, V. Latvijas PSR valsts un tiesību vēsture. 1. d. Rīga: Zvaigzne, 1972. 
16. Kamchatov, K. V., Chashchina, I. V., Velikaia, E. V. Vozobnovlenie proizvodstva po ugolovnomu delu. Moskva: Akademiia generalnoi prokuraturi Rossiiskoi Federatcii, 2016. (Камчатов, К. В., Чащина, И. В., Великая, Е. В. Возобновление производства по уголовному делу. Москва: Академия генерахьной прокуратуры Российской Федерации, 2016).

17. Kriminālprocess (pēc lekcijām, lasītām Latvijas Universitātē 1931. g.): 1.-18. lekcija. No: Augstskola mājā: Tiesību zinātṇu nodaḷa, Nr. 77-86. Rīga: Herolds, 1930.

18. Latvijas tiesību vēsture, 1914-2000: Mãcību grāmata juridiskajām augstskolām un fakultātēm. Rìga: Fonds "Latvijas vēsture", 2000.

19. Lazdiṇš, J. Krievijas Senāta judikatūras nozīme Baltijas tiesību piemērošanas problēmu jautājumos (1864-1917) (Kuršu ḳoniṇu lieta). No: Aktuālas tiesību realizācijas problēmas: Latvijas Universitātes 69. konferences rakstu krājums. Rīga: LU Akadēmiskais apgāds, 2011. Iegūts no: https://www.lu.lv/fileadmin/user_upload/lu_portal/apgads/PDF/Juristu-konf-69.pdf [sk. 27.12.2017.].

20. Lazdiṇš, J., Blūzma, V., Osipova, S. Latvijas tiesību avoti: Teksti un komentāri. 1. sēj. Rīga: Latvijas vēsture. 1998.

21. Liede, A. Daži vārdi par kriminālprocesa teoriju. Rīga, 1940.

22. Liede, A. Latvijas PSR Kriminālprocess: Tiesvedības norise krimināllietās. Rīga: Zvaigzne. 1973.

23. Liede, A. Latvijas PSR Kriminālprocess: Vispārīgā daḷa un tiesu pierādījumi. Rīga: Zvaigzne $\mathrm{ABC}, 2010$.

24. Meikališa, Ā. 50 gadi Latvijas kriminālprocesuālajā likumdošanā - virzieni, rezultāti, perspektīvas. No: Kriminālprocess. Raksti 2010-2015. Rīga: Latvijas Vēstnesis, 2015.

25. Nersesiantc, V. S. Filosofiia prava: uchebnik dlia vuzov po iuridicheskim spetcialnostiam. Moskva: Norma, 2003. (Нерсесянц, В. С. Филособия права: учебник для вузов по юридическим специальностям. Москва: Норма, 2003).

26. N̦ikiforova, I. Kriminālprocesa attīstības process pasaules kontekstā. Daugavpils Universitātes 53. starptautiskās zinātniskās konferences materiāli. 2014. Iegūts no: https://www.dukonference.lv/lv/content_53 [sk. 21.01.2018.].

27. Rozin, N. N. Ugolovnoe sudoproizvodstvo: posobie k lektciiam. 4 izd. Riga: Gliksman, 1924. (Розин, Н. Н. Уголовное судопроизводство: пособие к лекииям. 4 изА. Рига: Гииксман, 1924).

28. Rusanovs, E. Latvijas kriminālprocesa doktrīnas meklējumos. Jurista Vārds. 1(853), 06.01.2015., 2-17.

29. Smirnov, A. V., Kalinovskii, K. B. Ugolovnii protcess: posobie dlia podgotovki k ekzamenu. SanktPeterburg: Piter, 2004. (Смирнов, А. В., Кахиновский, К. Б., Уголовный процесс: пособие для подготовки к экзамену. Санкт-Петербург: Питер, 2004).

30. Strogovičs, M. S. Kriminalprocess: Mācības grāmata juridiskām skolām. Rīga: Latvijas Valsts izdevniecība, 1946.

31. Strogovičs, M. S. Kriminalprocess: Mācības grāmata juridiskiem institutiem un fakultātēm. Rìga: Latvijas Valsts izdevniecība, 1949.

32. Šulcs, L. Kriminalprocess: lekcijas. Rīga, 1940. 